\title{
ПУБЛІЧНЕ АДМІНІСТРУВАННЯ ЯК РЕАЛІЗАЦІЯ УПРАВЛІНСЬКИХ РІШЕНЬ
}

\section{Бліхар М. М.}

\section{ВСТУП}

Вивчення особливостей здійснення публічного адміністрування в сучасних умовах державотворення в Україні актуалізується в умовах здійснення реформи місцевого самоврядування. Публічне адміністрування повинно бути комплексним та повним процесом управлінської діяльності, основаним на розмежуванні сутності централізації та децентралізації управлінської гілки влади. Хоча термін «публічна адміністрація» був розроблений, поширений та нині застосовується у багатьох країнах континентальної системи адміністративного права, в українському законодавстві до сих пір остаточно не сформовано єдиного законодавчого підходу щодо цього поняття. Під час розгляду публічного адміністрування часто пропонується широкий спектр тверджень і визначень, які розкривають окремі аспекти цього поняття та підходи до його розуміння. Найбільш поширеним $\epsilon$ розгляд публічного адміністрування в аспекті його організаційно-структурної будови та аналізу функціонального призначення в системі державної та місцевої влади.

\section{1. Публічне адміністрування:}

\section{теоретичні засади та підходи до визначення}

Публічне адміністрування - регламентована законами та іншими нормативно-правовими актами діяльність суб'єктів публічного адміністрування, спрямована на здійснення законів та інших нормативно-правових актів шляхом прийняття адміністративних рішень, надання встановлених законами адміністративних послуг ${ }^{1}$ Публічне адміністрування здійснюється публічною адміністрацією, тобто системою певних публічних інституцій, яка складається із державних та недержавних суб'єктів публічної влади, ключовими структурними елементами якої є органи виконавчої влади і виконавчі органи місцевого самоврядування.

1 Основи публічного адміністрування : навч. посібн. / за заг. ред. Н.П. Матюхіної. Харків : Право, 2018. С. 8-9. 
Сутність суб'єкта публічного значення полягає в його ролі та владних повноваженнях у публічному адмініструванні, а також управлінських можливостях, які випливають 3 його владної компетенції та динамічної взаємодії всіх елементів його компетенції. Компетенція розглядається як комплекс взаємопов'язаних елементів (мети, завдань, предмета відання та повноважень), що характеризує особливості діяльності конкретного суб'єкта публічного адміністрування, зумовлені його місцем у публічній адміністрації Відповідно до компетенції суб'єкта публічного адміністрування органи виконавчої влади можна поділити на: органи загальної компетенції; органи галузевої компетенції; органи міжгалузевої компетенції; органи функціональної компетенції; органи предметної компетенції ${ }^{2}$. О. Джафарова розглядає дозвільну компетенцію органів публічної адміністрації як сукупність прав та обов'язків (правообов'язків), а також спрямованість останніх на забезпечення життя, здоров'я людини, безпеки навколишнього природного середовища, національних інтересів та підтримання балансу приватних та публічних інтересів у певній сфері суспільних відносин (економічній, екологічній, культурній $)^{3}$. В Енциклопедії державного управління публічне адміністрування розглядається як різновид управлінської діяльності інституцій публічної влади, завдяки якій громадянське суспільство та держава забезпечують самокерованість (самоврядність) усієї суспільної системи та ії розвиток у певному напрямі ${ }^{4}$. Проте, як зазначав німецький філософ і соціолог Ю. Габермас, населення повинно володіти достатньою інформацією щодо діяльності керівного апарату, оскільки саме інформація $\epsilon$ ключовою у вирішенні проблем або конфліктів у суспільстві та допомагає суспільству обговорювати та викладати свої потреби перед владою і відповідно здійснювати контроль над процесом реалізації поставленого перед владою питання. Але оскільки, як зазначає Ю. Габермас, «публіка (незалежні громадяни) сама правити не може, вона може лише контролювати дію адміністративної влади, урядових інститутів і направляти їх у необхідному річищі (руслі)»), залишається важливим при здійсненні управління суспільними справами приділяти

2 Адміністративне право України. Повний курс : підручник / В. Галунько, П. Діхтієвський, О. Кузьменко, С. Стеценко та ін. Херсон : ОЛДІ-ПЛЮС, 2018. С. 82.

3 Джафарова О.В. Дослідження органів публічної адміністрації в системі суб'єктів дозвільної діяльності в Україні. Форум права. 2018. С. 44.

${ }^{4}$ Енциклопедія державного управління: у 8 тт. Т. 8 : Публічне врядування / наук. ред. кол. : В.С. Загорський та ін. Львів : ЛРІДУ, НАДУ. 2011. 489 с.

${ }^{5}$ Habermas, J. (1992), Further Reflections on the Public Sphere. Habermas and the public sphere / edited by C. Calhoun. The MIT Press, Cambridge, Massachusetts, and London, England, p. 137. 
значну увагу публічності прийняття і реалізації владних рішень для забезпечення загального суспільного інтересу.

О. Митяй та О. Світовий наголошують на адмініструванні саме як на прерогативі виконавчих органів влади або чиновника (державного службовця), а суттю адміністрування визначають процедуру втілення рішень, встановлених в системі управління ${ }^{6}$.

Публічне адміністрування у більш ширшому розумінні включає в себе систему державного управління, представленого чинними адміністративними інститутами в рамках прийнятої структури влади в Україні. О. Амосов вказує, що поняття «публічне адміністрування «у суспільстві межує із функціонування усіх трьох гілок влади законодавчої, виконавчої та судової․ Розглядаючи адміністрування як особливий вид суспільного управління щодо створення, запровадження, оцінювання та модифікації публічної влади, в межах усього суспільства під категорією публічного адміністрування розуміють всю систему інститутів адміністративного права разом із владною ієрархією, завдяки якій відповідальність за реалізацію та ефективність провадження здійснюється «згори» 8 .

Разом із тим можна розглядати i більш вузьке визначення публічного адміністрування, яке пов'язують саме із виконавчою гілкою влади на рівні центральної, місцевої адміністрації або місцевого самоврядування, і таким чином простежується зв'язок із професійною діяльністю державних службовців усіх видів державної служби та представницькими органами місцевого самоврядування, спрямованою на реалізацію рішень виконавчої влади; сюди ж можна віднести вивчення, розробку та впровадження в держану практику напрямів державної політики в різних сферах суспільного життя.

Окремі дослідники, зокрема Гошовська В., Лазор О., вбачають у публічному адмініструванні реалізацію «публічної влади» як «поєднання державного управління та громадського самоврядування» ${ }^{9}$,

${ }^{6}$ Митяй О. В., Світовий О. М. Дослідження понять «державне управління» і «публічне адміністрування». Держава та регіони. Серія : Державне управління. 2018. № 1(61). C. 126.

Амосов О.Ю., Гавкало Н.Л. Публічне адміністрування: методологічний контекст. Публічне управління XXI століття: від сочіального діалогу до суспільного консенсусу: збірн. тез до XIV Міжнар. наук. конгресу. Харків : Магістр, 2014. С. 12.

8 Демократичні стандарти врядування й публічного адміністрування: матер. наук.-практ. конф. за міжнар. участю (м. Львів, 4 квітня 2008 р.). У 2 ч. Ч. 1. Львів : ЛРІДУ НАДУ, 2008. 187.

9 Гошовська В.А. Публічна політика; Енциклопедичний словник з державного управління; уклад.: Ю. Сурмін, В. Бакуменко, А. Михненко [та ін.]. Київ : НАДУ, 2010. С. 604; Лазор Л.Я., Лазор Л.Д. Публічне управління та адміністрування: ретроспектива деяких теоретичних аспектів. Університетські наукові записки. 2015. № 56. C. 114. 
оскільки у сучасному світі неможливо уявити реалізацію демократії як форми суспільної влади без зростання впливу громадських інституцій, громадського самоврядування, спрямованих, у першу чергу, на реалізацію адміністративних функцій громадянського суспільства. Отже, найчастіше публічне адміністрування пов'язують із функціями виконавчої влади, із здійсненням професійних функцій державними службовцями на виконання доведених для них управлінських рішень, впровадження державної політики.

Слід зауважити, що дослідники публічного адміністрування у вузькому розумінні до органів публічної адміністрації відносять органи виконавчої влади та органи місцевого самоврядування ${ }^{10}$; у ширшому сприйнятті терміна публічного адміністрування ця категорія органів публічної адміністрації доповнюється за рахунок включення до неї суб'єктів делегованих повноважень та органів державної влади, які не мають статусу органу виконавчої влади, а подекуди й за рахунок приватних осіб тощо ${ }^{11}$. Для прикладу, К. Колесникова наголошує на полісемантичному характері категорії «публічне адміністрування», яка розглядається як «публічне адміністрування», «публічна адміністрація», «громадське управління», «управління на державному і місцевому рівні», «громадська адміністрація» ${ }^{12}$.

Здійснюючи переклад 3 англійської термінів, пов'язаних із публічним управлінням, в англомовній науковій літературі, Кілієвич О. розрізняє споріднені поняття «public sector», «public policy» та «public administration», наголошуючи, що саме термін «public administration» слід розглядати як державне управління, або ж як впровадження державної політики переважно виконавчою гілкою влади ${ }^{13}$.

${ }^{10}$ Стеценко С.Г. Адміністративне право України : навч. посіб. Київ: Атіка, 2011. С. 49; Авер'янов В.Б. Реформування українського адміністративного права: грунтовний привід для теоретичної дискусії. Право України. 2003. № 5. С. 117; Міхровська М. Державне управління та публічна адміністрація: шлях до демократії. Вісник Київського національного університету імені Тараса Шевченка (Юридичні науки). 2011. № 88. С. 92.

${ }^{11}$ Адміністративне право України (у визначеннях та схемах) : навч. посіб. / С.О. Масьондз. Київ: Атіка, 2008. С. 89; Публічна адміністрація в Україні: становлення та розвиток : монографія / за заг. ред. А.В. Толстоухова. Дніпро : Монолит, 2010. С. 24; Петров Є.В. Феноменологія адміністративно-господарського права України : монографія. Харків : Диса плюс, 2012. С. 204.

${ }^{12}$ Колесникова К.О. Публічне адміністрування в Україні: огляд літературних джерел. URL : http//www.kbupapa.kharkov.ua/e-book/tpdu/2013-3/doc/1/16.pdf (дата звернення: 24.10.2020). С. 2.

${ }^{13}$ Кілієвич О. Англо-український глосарій термінів і понять 3 аналізу державної політики та економіки. Київ : Основи, 2003. 510 с. 
Аналізуючи термін «процес управління», К. Бугайчук, зокрема, вказує на наявність підходів до його розуміння: як процесу управління через сукупність певних етапів (дій, операцій), що існують у соціальних системах та $є$ циклічно повторюваними; як процесу управління через виконання (або пов'язується 3 виконанням) функцій управління; як процесу управління через діяльність певних суб'єктів (керівників) ${ }^{14}$.

Можна погодитися 3 розумінням поняття «публічне адміністрування» як комплексної усвідомленої та цілеспрямованої діяльності, що пов'язана 3 реалізацією повноважень суб'єктів управління із розробки, прийняття та впровадження державноуправлінських рішень або послідовного здійснення управлінського циклу, що складається із класичних функцій управління, таких, як планування, організація, мотивація, контроль, та впливає на зміну суспільних процесів та явищ, наближаючи їх до бажаного стану згідно 3 визначеними управлінськими цілями організації ${ }^{15}$.

Таке формулювання публічного адміністрування передбачає розгляд його функціонування як певного універсального правового механізму для управління суспільною організацією та прийняття управлінських рішень для учасників суспільних процесів, формування зон відповідальності. Недостатній рівень правового регулювання владних повноважень, особливо державних службовців, відсутність прозорості та відкритості у сфері прийняття і реалізації державного управління, недосконалість механізму політичного, адміністративного та публічного контролю в системі публічного управління можуть стати вагомими негативними чинниками у деструкції організаційної системи публічного адміністрування.

Результатом цієї адміністративної діяльності, зазвичай, є здійснення спеціально уповноваженим суб'єктом публічного адміністрування певних адміністративних дій, які повинні бути представлені в певній нормативно-правовій формі і вигляді, наприклад наказу, директиви, розпорядження тощо ${ }^{16}$. Такі адміністративні дії здійснюються даними суб'єктами управління у межах закріплених за ними посадових повноважень, а також шляхом застосування спеціальних форм та методів, спрямованих на реалізацію основних функцій публічного адміністрування задля реалізації адміністративної мети i координування управлінськими ресурсами.

14 Бугайчук К. Процес публічного адміністрування в органах національної поліції України. Підприємництво, господарство і право. 2019. № 3. С. 138.

${ }^{15}$ Кальниш Ю.Г., Лозинська Т.М., Тимцуник В.І. Публічне адміністрування : навч. посібн. Полтава : РВВ ПДАА, 2015. С. 6-8.

16 Система адміністративного менеджменту та апарат управління. Адміністративний процес. URL : https://goo.gl/EJat4у (дата звернення: 24.10.2020). 
У цьому аспекті важливо наголосити на структуруванні публічного адміністрування як виду управлінської діяльності, виокремивши такі складові сегменти (блоки) в адміністративно-правовому статусі органів виконавчої влади, як цільовий, структурно-організаційний та компетенційний (компетенцію). Для прикладу, окремі дослідники адміністративного права до першого сегмента адміністративноправового статусу відносять цілі, завдання та функції, що закріплені юридично, до другого сегмента - організаційно-структурний компонент правового статусу, який охоплює нормативне регулювання порядку створення, легалізації, реорганізації, ліквідації суб'єктів їхньої підзвітності, встановлення та зміни їхніх організаційних структур, права та організаційне самовизначення, процедури діяльності та права на офіційні символи ${ }^{17}$.

Важливим маркером дійсної публічності влади та адміністрування суспільного життя $є$ саме здійснення адміністрування на принципах публічності. Як відомо, громадянське суспільство найбільш ефективно діє на регіональному та місцевому рівнях, саме на тих рівнях, на яких вибудовуються відносини органів публічної влади та громадян щодо управління щоденними потребами суспільства в питаннях організації нагальних життєвих проблем та взаємодії різноманітних суб'єктів господарювання, тобто створення та функціонування певного суспільного простору. Як правило, така публічність здійснюється шляхом взаємодії державної централізованої влади із регіональною та місцевою. І. Шумляєва наголошує, що саме на місцевому рівні територіальні громади, як частина суспільства, впливають на становлення правової державності через публічно управлінські процеси, зокрема ті, які стосуються прийняття публічно управлінських рішень, удосконалення правової бази стосовно реалізації ними права на місцеве самоврядування ${ }^{18}$.

Використання принципу публічного управління - це застосування відношення або взаємозв'язку суспільно-політичної природи та інших елементів публічного управління, що виражені як певне наукове положення, що закріплене правом у законодавчому акті та застосовується в теоретичній та практичній діяльності людини в управлінні через публічні адміністрації ${ }^{19}$.

17 Золотарьова М.К. Адміністративно-правовий статус державних податкових інспекцій : монографія. Запоріжжя : КПУ, 2010. С. 25.

${ }^{18}$ Шумляєва І. Розвиток взаємовідносин органів публічної влади та громадян на місцевому рівні в умовах формування правової держави. Державне управління та місиеве самоврядування. 2019. Вип. 2(41). С. 163.

19 Методологія публічного управління : навчальний посібн. / укладач І.В. Шпекторенко. Дніпро : ДРІДУ НАДУ, 2018. 120 с. 
У цьому контексті, такі дослідники, як Дзюндзюк В., Мельтюхова Н., Фоміцька Н., наголошують на тому, що використання принципу публічності влади та розвиток публічного адміністрування характерні лише в останні роки для пострадянського суспільства, в тому числі й України, та пов'язують це із тим, що для тоталітарного режиму єдиним способом управління усіма сферами суспільного життя, і економіки, і виробництва, і освіти, i науки, i культури, i мистецтва, і соціальної сфери чи навіть приватного життя громадян, було саме державне управління ${ }^{20}$. Лише 3 переходом до ринкових відносин «розвантаження» суспільства від тотального впливу держави починають природно формуватися інші універсальні способи впливу на управління суспільним життям i суспільними відносинами для забезпечення стійкого функціонування суспільства як цілісної системи.

Публічність влади, на думку А. Селіванова, стає однією з юридичних ознак участі держави в суспільних відносинах, що врегульовано позитивним правом через приймання громадянами Конституції України як Основного Закону, через публічність управління громадяни погоджуються із переданням і відчуженням державі окремих природних суб’єктивних прав. Отже, на думку вченого, публічна влада за своєю конституційно-правовою характеристикою набуває ознак правосуб'єктності від суверенітету народу ${ }^{21}$.

Разом із цим для публічного особливо важливим $є$ принцип законності, що передбачає пріоритет закону та спрямований на утвердження міцних правових засад не лише в державному управлінні, але й у всіх сферах діяльності держави. Він полягає в необхідності переважно визначення на законодавчому рівні основних функцій, цілей, організаційних структур, процесів, принципів публічного управління i адміністрування. Особливо важливим $є$ прийняття управлінських рішень у публічному адмініструванні на основі чинного законодавства і тільки з урахуванням їх відповідності чинним правовим актам. Це основа нормотворчої та правозастосовної діяльності апарату публічного адміністрування, що спрямована на правове регулювання правовідносин, що виникають у різних галузях прийняття управлінських рішень.

Управлінська діяльність, незважаючи на їі зовнішню простоту, має велике методологічне значення, оскільки вона відбувається

${ }^{20}$ Дзюндзюк В.Б., Мельтюхова Н.М., Фоміцька Н.В. Публічне адміністрування в Україні. Харків : Магістр, 2011. 306 с.

${ }^{21}$ Селіванов А.О. Публічна влада і громадянин в умовах застосування судової адміністративної юрисдикції (проблеми теорії і практики). Право Украӥни. 2006. № 9. C. 32 . 
і виконується на всіх рівнях управління соціальної системи. При цьому методологія публічного адміністрування повинна містити комплекс методів та методологічних зв'язків між різними інститутами публічного адміністрування та державного управління і з дотриманням основоположних прав та свобод людини та громадянина. Публічне адміністрування повинно утримувати баланс інтересів держави та інтересів громадян, територіальних, громадських утворень, соціальних спільнот, у сфері забезпечення державного управління.

Удосконалення методології державного управління через публічне адміністрування в Україні запропоновано розглядати через такі напрямки, як: концептуалізація, проектування, наукове обгрунтування та забезпечення категоріально-понятійним апаратом, моделювання, модернізація ${ }^{22}$.

Із іншого боку, публічність здійснення владних повноважень сприяє включенню громадян до вирішення питань загальнодержавного та місцевого значення через більшу поінформованість значної кількості учасників-суб'єктів управлінської діяльності, так і громадян, які зацікавлені у прийнятті управлінських рішень, корисних для усієї громади. Це дозволяє ухвалювати рішення, враховуючи настрої громади, які, у свою чергу, можуть вказати на більш конкретні актуальні проблеми, що вимагають нагального вирішення, дозволяє оцінювати ефективність управлінських рішень зі сторони споживачів управлінських рішень. А це для громадян, які володіють конституційним правом брати участь в управлінні державними справами, на думку В. Алексєєва, $€$ важливим аргументом для сучасного суспільства, що розвивається зовсім за іншими, кардинально відмінними від попередніх часів, принципами демократичності, публічності, залучення громадян в управління державою на різних рівнях управління, особливо на місцевому i регіональному ${ }^{23}$, розширення правової бази місцевого самоврядування, іï здатність бути базисом системи територіальної організації влади в Україні. Саме в такому розумінні розглядається публічна адміністрація польським дослідником i реформатором М. Кулешею, саме як «сукупність організаційних дій, діяльності та заходів, які виконуються різними суб'єктами та інституціями на основі закону та в межах, визначених законом, для досягнення публічного інтересу» ${ }^{24}$.

22 Методологія публічного управління : навчальний посібн. / укладач I.В. Шпекторенко. Дніпро : ДРІДУ НАДУ, 2018. С. 104-105.

23 Алексєєв В.М. Взаємовідносини держави та суспільства в Україні: управлінський аспект : монографія. Чернівці : Технодрук, 2010. С. 17.

${ }^{24}$ Школик А.М. Порівняльне адміністративне право. Львів : ЗУКЦ, 2007. С. 10. 
Однак не слід забувати, що публічне адміністрування спрямовується і орієнтується не тільки на окремого громадянина, але й на права, обов'язки та інтереси широкого кола фізичних та юридичних осіб, що здійснюють свою підприємницьку та інші види діяльності на певній території, підпорядкованій конкретній публічній владі.

Проте публічність адміністрування - це не тільки поінформованість про дії влади, не лише передання владних повноважень на рівні місцевого самоврядування. Йдеться передусім про зміну управлінських компетенції та статусних характеристик органів публічної влади, а це виносить на порядок денний необхідність їх концептуального чіткого визначення та розробки нових механізмів публічного управління для забезпечення нормативно-правового та структурно-організаційного функціонування суб'єктів публічного адміністрування. О. Молошна акцентує увагу на тому, що публічне адміністрування передбачає функціонування універсального організаційно-правового механізму виявлення, узгодження й реалізації суспільних потреб та інтересів, формування прав і обов'язків учасників суспільних процесів та їх взаємовідносин у правовому полі ${ }^{25}$. Такий підхід до побудови $\mathrm{i}$ реалізації владних повноважень у системі публічного адміністрування повинен спрямовуватися на забезпечення вирішення таких завдань адміністрування: формування системи державної влади на різних рівнях централізації і децентралізації, місцевому рівні управління та вдосконалення механізмів їхньої інтеграції; вдосконалення управлінської моделі раціональної взаємодії органів державної влади 3 органами місцевого самоврядування, надання цим відносинам правових ознак публічності, зокрема, через забезпечення та реалізацію прав $\mathrm{i}$ свобод громадян у сфері державного управління.

Як зазначає О. Зарічний, Європейська хартія місцевого самоврядування закріплює розуміння місцевого самоврядування як права i реальну здатність органів місцевого самоврядування регламентувати значну частину державних справ і здійснювати надані їм владні повноваження відповідно до чинного законодавства, застосовуючи владну відповідальність на реалізацію та забезпечення потреб місцевого населення. У цьому плані місцева чи регіональна влада $\epsilon$ необхідним елементом державного адміністрування, і іiі не можна розглядати як менш важливу чи другорядну у порівнянні із центральною державною владою. Важливою особливістю публічного

25 Молошна О.Л. Особливості формування державно-службових відносин в умовах становлення системи публічного адміністрування в Україні. URL : http://www.dridu.dp.ua/vidavnictvo/2009/2009-02(2)/ Moloshna,\%20Bashtannyk.pdf (дата звернення: 24.10.2020). 
адміністрування на місцевому чи регіональному рівнях $\epsilon$ сконцентрованість уваги на проблемах конкретної громади з огляду на ментально-територіальні особливості громадян певної території ${ }^{26}$. Запровадження моделі публічного адміністрування в системі державної влади та адміністративно-територіальному устрої держави вимагає розгляду публічного адміністрування та публічної служби як єдиного i цілісного інституту, який побудований на єдиних принципах і який би комплексно реалізовував публічну владу. Доводиться констатувати, що у вітчизняному законодавстві не сформовано підходів до відповідного розуміння публічної служби. Також це потребує їх відповідного правового оформлення та підготовки відповідного кадрового забезпечення публічного адміністрування. Тому для забезпечення функціонування механізмів регулювання діяльності органів державної влади необхідно забезпечити організацію сучасної системи підготовки та перепідготовки управлінських кадрів. Адже, як зазначають Г. Алмонд і С. Верба, «державні діячі, які намагаються створити політичну демократію, дуже часто зосереджують свої зусилля на встановленні певного набору демократичних урядових інститутів i написанні конституції. Проте для розвитку стабільного й ефективного демократичного врядування необхідно дещо більше, аніж певні політичні та управлінські структури. Цей розвиток залежить від політичної культури. Якщо вона не здатна утримувати демократичну систему, шанси останньої на успіх замалі» ${ }^{27}$.

На наш погляд, у реалізації публічного адміністрування важливою формою взаємодії громадськості і держави $є$ проведення органами публічної влади моніторингу й аналізу громадської думки, участь інституцій громадянського суспільства у виробленні та обговоренні публічно-адміністративних рішень, здійснення суспільними організаціями громадського контролю діяльності органів публічної влади та відповідності прийнятих управлінських рішень інтересам широких верств населення, створення консультативних, експертних та дорадчих органів і т.п. Такий суспільний контроль та співучасть у прийнятті публічно-правових управлінських рішень сприятиме перетворенню адміністрування у прозорий та публічний процес, ширшому охопленню інтересів учасників приватно-публічного адміністрування, підвищенню відповідальності та правової культури суб'єктів публічного адміністрування. Особливо важливою $є$ така

26 Зарічний О.А. Участь громадськості у здійсненні публічної влади: теоретикоправове дослідження : дис. ... канд. юрид. наук. Львів, 2017. С. 23.

${ }^{27}$ Цит. за. Зарічний О.А. Участь громадськості у здійсненні публічної влади: теоретико-правове дослідження : дис. ... канд. юрид. наук. Львів, 2017. 
публічність у вирішенні соціально-економічних проблем на місцевому і регіональному рівнях.

Як бачимо, публічне управління, на відміну від державного управління, сприятиме втіленню суверенітету народної влади, демократичності прийняття управлінських рішень, реалізації суспільних інтересів без підміни їх державними. Крім того, публічне адміністрування значно розширює кількість суб'єктів, що зацікавлені і беруть участь в адмініструванні, оскільки сюди активно залучаються органи місцевого самоврядування.

\section{2. Вплив публічного адміністрування \\ на формування державної політики}

Загалом, публічне адміністрування змінює практику впровадження державної політики. Для прикладу, П. Петровський виокремлює дві основні парадигми державного управління - директивну та партисипативну, відмінність між якими полягає у площині визначення суб'єктів політико-правових рішень. Відповідно до директивної парадигми управління таким суб'єктом визнається єдиний керуючий центр, наприклад, орган державної влади, а всі інші учасники $€$ виконавцями. На відміну до директивного підходу в управлінні, партисипативна парадигма передбачає активну участь виконавців у прийнятті та реалізації рішень, можливість прояву ними ініціативності, творчості, підвищення відображення в управлінських рішеннях, розв'язання актуальних проблем сьогодення тощо. Сучасне демократичне управління намагається включати в себе обидві управлінські парадигми, а публічне адміністрування значною мірою грунтується на засадах партисативної парадигми. Їх застосування залежить від таких важливих для прийняття управлінських рішень факторів, як зміст управлінського рішення, популярність проблеми чи завдання, яке воно вирішуватиме у суспільстві загалом, конкретній громаді чи для окремого громадянина, готовність суб'єктів управління до виконання такого рішення, наявність організаційних, матеріальних, фінансових, інформаційних та інших ресурсів для виконання та досягнення позитивного результату від прийнятого управлінського рішення $^{28}$. Рівень застосування партисипативної парадигми в публічному управлінні визначатиметься, значною мірою, ступенем втручання держави у приватні відносин та відносини місцевого самоврядування, характеру контрольної та наглядової діяльності

28 Петровський П., Радченко О. Гуманітарна парадигма як теоретикометодологічна модель демократичного врядування. Ефективне державне управління: збірн. наук. пр. 2011. № 26. С. 13-22. 
держави в особі iї спеціально створених державних органів, рівня участі громадськості у місцевому самоврядуванні та загальнодержавних справах тощо.

Тому розширення публічного адміністрування вимагає відповідним чином систематизувати засоби нормативно-правового забезпечення публічного адміністрування. У свою чергу, це дозволить адаптувати законодавство України до законодавства $Є С$ стосовно реалізації публічного адміністрування.

Отже, управлінські рішення під час здійснення публічного адміністрування встановлюються, змінюються i припиняються обов'язково на основі норм адміністративного права, таким чином вони спричинюють настання саме юридичних наслідків як для суб'єктів публічного адміністрування, так i загалом для інших суб'єктів господарської діяльності, користувачів соціальної сфери тощо, прямо або опосередковано. Тому форми публічного адміністрування завжди $\epsilon$ правовими, а отже, повинні розглядатися в межах адміністративного права лише як ті види діяльності публічної адміністрації, що призводять до настання юридичних наслідків.

Зміна акценту правового впливу здійснення владних повноважень, розгляд державних службовців та посадових осіб органів місцевого самоврядування як публічних службовців та здійснення публічного контролю та наглядом за управлінськими функціями у суспільстві 3 боку його громадян впливає на розширення видів управлінської діяльності, виокремлюючи їх спільні та відмінні риси й характеристики в нових умовах демократизації владних повноважень. Це ж відбувається і під час підготовки та здійснення (реалізації) цих рішень, прийняття до виконання нормативно-правових актів юридичними та фізичними особами, участі громадськості у виробленні пропозицій із питань публічної політики на регіональному і місцевому рівнях i, таким чином, впливу суспільства на здійснення публічного адміністрування на рівні усієї держави.

Сучасні тенденції публічного адміністрування вказують на необхідність розмежування управлінської влади через трансформацію понятійно-категорійного апарату публічного адміністрування, визначення питань, що належать до управління публічними особами державного та місцевого значення, закріплення особливості у вирішенні методами (визначення методів) публічного адміністрування в нормативно-правовому полі, здійснення розмежування компетенцій суб'єктів публічної влади на державному, регіональному і місцевому рівнях. Окрім того, сучасна правова концепція публічного управління та адміністрування розглядає їх як наслідок зусиль до відкриття публічного управління, як «відвоювання політичного авторитету 
соціальних суб'єктів» ${ }^{29}$. Унаслідок цього державне управління перестало бути єдиним, а отже, бюрократичним способом здійснення управління у суспільстві. Зменшуючи, в такому випадку, дисфункціональну спроможність чиновників одноосібно впливати на форми та методи взаємодію влади у суспільстві, визначаючи нагальної суспільної потреби у пошуках постмодерної (постбюрократичної) суспільної моделі, яка б визнавала примат інтересів людини та громадянина над владою державного апарату, необхідність ії активного залучення свідомого та освіченого населення до сфери публічної політики та адміністрування, підвищення ефективності та результативності публічного управління, визначення основних критеріїв якості діяльності державної та публічної адміністрації тощо ${ }^{30}$.

Підвищення ефективності суспільного управління через удосконалення публічного адміністрування відбувається у зв'язку із децентралізацією владних повноважень на регіональному та місцевому рівнях, що сприяє організаційній та соціальній результативності внаслідок уточнення суспільних потреб та засобів на територіальних рівнях, спрощення регулятивного законодавства у сфері економіки, зменшення бюрократичного тиску та навантаження на підприємців середнього та малого бізнесу, оскільки вони тісно прив'язані до різного виду дозволів, сертифікатів, розпоряджень. Публічність управлінської діяльності та адміністрування на місцевому та регіональному рівнях залучатиме ширші верстви активного населення до управлінської співпраці, a, отже, формування ефективної системи публічного адміністрування.

Розвиток публічного адміністрування сприяє постійній та активній взаємодії держави, іiї органів та структур, державних службовців із недержавним сектором, дозволяє враховувати сучасну складну систему соціальних взаємозв'язків, динамічні аспекти розвитку економіки та соціальної сфери, тобто комплексно враховувати тенденції суспільного розвитку на конкретному історичному етапі. Такий розвиток враховує не лише горизонтальні, а й множинні вертикальні зв'язки та розподіл владних повноважень через формування чітких управлінських повноважень та управлінської відповідальності, враховуючи множинність та взаємопов'язаність управлінських політик, програм та проєктів на різних рівнях їх реалізації. Важливим залишається розподіл за правовою основою, дизайн владних повноважень із обов'язковим

${ }^{29}$ Andersen S., Burns T. The European Union and the erosion of parliamentary democracy: a study of post-parliamentary governance. The European Union: how democratic is it? London: Sage, 1996. P. 228.

30 Демченко Л. Критика теорії і практики бюрократії. Public Administartion Aspects. 2019. № 7(5). С. 10. 
оцінюванням соціальної ефективності та передбачуваності управлінських рішень.

Реформування системи державного управління через впровадження публічного адміністрування повинно здійснюватися через оптимізацію функцій інститутів державної влади для побудови ефективної моделі управління, визначення та розподілу зон службових повноважень i службової відповідальності, реалізація публічності управлінської структуру взаємовідносин суб'єктів управління та громадськості, що повинна здійснювати публічний контроль за адмініструванням суспільного життя. Така перебудова управлінської діяльності через прийняття принципів публічності, демократичності, 3 врахуванням історичного моменту на даному етапі соціального розвитку країни повинна спрямовувати пріоритетні напрямки управління на побудову ефективної соціально-орієнтованої системи публічного адміністрування. Соціально-орієнтована система публічного адміністрування повинна надавати суб'єктам - споживачам управлінських рішень якісних адміністративних послуг на усіх рівнях суспільної організації, котрі повинні відповідати сучасним європейським та світовим стандартам, вчасно враховувати та адекватно реагувати на можливі політичні, зовнішньополітичні соціально-економічні, культурні та інші виклики сучасності.

Закладення чіткого правового базису публічного адміністрування в Україні передбачає розподіл політичної та адміністративної сфер діяльності державних органів та місцевих органів самоврядування. Але, своєю чергою, такий чіткий правовий базис надбудови публічного адміністрування повинен враховувати і цілісність та незалежність адміністративної судової системи, створення системи ефективного фінансового менеджменту з чітким регламентуванням відповідальності за порушення управлінської дисципліни, забезпечення високого професійного рівня державних службовців та спеціалістів місцевого самоврядування, оптимізацію процесу формуванням кадрової політики, підвищення якості надання послуг у сфері державного управління, підвищення етичної складової частини системи публічного адміністрування, забезпечення публічності у прийнятті та реалізації прийнятих ними управлінських рішень.

\section{ВИСНОВКИ}

Зміни в теоретичних підходах до розуміння держаного управління та адміністрування вимагають підвищення ролі регіонального та місцевого самоврядування, а саме: орієнтації на управлінські ініціативи з боку місцевого самоврядування. Публічність допомагає процесу децентралізації, що створює умови для розширення горизонтальної співпраці за більш детального розуміння реальних місцевих проблем. Це 
зумовлює важливість публічності в процесі державного управління i здатності суб'єктів публічного адміністрування забезпечити створення ефективної та дієздатної системи управління державою, у тому числі через підвищення рівня іï публічності. Для цього публічне адміністрування повинно спиратися на цілісний апарат відповідного адміністративного впливу (політику, елементи правової системи, правила, процедури, організаційні структури, персонал тощо), які повинні бути зосереджені саме на перетворенні управлінської діяльності на публічне адміністрування. Застосування публічного управління вимагає: врахування основних принципів розрізнення політичних $\mathrm{i}$ адміністративних питань; порівняльного аналізу загальнодержавних, політичних та економічних проблем й інтересів та проблем й інтересів бізнес-організацій; підвищення ефективності управлінської служби шляхом впровадження практики ділового адміністрування суб'єктів публічного адміністрування. Контроль зі сторони громадян, громадських організацій та дотримання публічності у роботі органів управління сприятиме дотриманню принципів верховенства права, забезпеченню прав i обов'язків людини та громадянина, а отже, зрештою забезпечуватиме розвиток громадянського суспільства та місцевого i регіонального самоврядування. Усі ці аспекти публічного адміністрування та публічного управління в сучасних умовах через введення в дію визначених управлінських стратегій, тактик, політик, програм розвитку дозволяють на значний період синхронізувати динаміку управління, узгоджено спрямувати різні галузі народного господарства, сфери людської діяльності, місцеві переваги та чинники на підвищення ефективності управлінської діяльності в напрямку досягнення загально значимих цілей держави у забезпеченні ефективного функціонування усього суспільства. Перспективи подальших досліджень публічного адміністрування полягають у пошуку функціональних особливостей публічного адміністрування у сфері державотворчого процесу та державно-приватного партнерства на місцевому чи регіональному рівні, що забезпечуватиме розбудову Української держави через делегування та передання окремих владних повноважень на місцевий рівень. Це дасть більше можливостей для реалізації значної кількості проєктів, що $є$ важливими саме на місцевому рівні чи в регіонах. Крім того, публічне адміністрування дозволяє розвивати різні моделі соціального управління шляхом розкриття та деталізації місцевих особливостей кожного регіону.

\section{АНОТАЦІЯ}

В умовах постійного розвитку нормативних актів, що регламентують діяльність органів управління в Україні, актуальною проблемою у побудові наукового підходу до державного управління $\epsilon$ 
розуміння суті публічного адміністрування як процесу державного управління та розробка концептуальних положень реалізації влади, як державної та виконавчої, так і місцевої (муніципальної), постійний аналіз процесу реалізації управлінських заходів, які здійснюються шляхом публічного адміністрування. А це неможливо розглядати без визначення сутності публічного адміністрування, зокрема, як процесу, його форм та методів, суб'єктів та об'єктів діяльності. Тому публічне адміністрування повинно бути проаналізоване як юридична, управлінська та соціальна категорія, розглянуті базові поняття та відмінності від споріднених правових категорій, мета, завдання, принципи діяльності, функції, форми та методи з урахуванням швидких динамічних змін, що відбуваються на сучасному етапі розвитку українського суспільства. Загалом, застосування публічного управління вимагає: врахування основних принципів розрізнення політичних $\mathrm{i}$ адміністративних питань; порівняльного аналізу загальнодержавних, політичних та економічних проблем й інтересів та проблем й інтересів бізнес-організацій; підвищення ефективності управлінської служби шляхом впровадження практики ділового адміністрування суб'єктів публічного адміністрування тощо. Недостатній рівень правового регулювання владних повноважень, особливо державних службовців, відсутність прозорості та відкритості у сфері прийняття і реалізації державного управління, недосконалість механізму політичного, адміністративного та публічного контролю в системі публічного управління можуть стати вагомими негативними чинниками у деструкції організаційної системи публічного адміністрування.

\section{ЛIТЕРАТУРА}

1. Авер'янов В.Б. Реформування українського адміністративного права: грунтовний привід для теоретичної дискусії. Право України. 2003. № 5. С. 117-122.

2. Адміністративне право України (у визначеннях та схемах) : навч. посіб. / С.О. Масьондз. Київ : Атіка, 2008. 272 с.

3. Адміністративне право України. Повний курс : підручник / В. Галунько, П. Діхтієвський, О. Кузьменко, С. Стеценко та ін. Херсон : ОЛДІ-ПЛЮС, 2018. 446 с.

4. Алексєєв В.М. Взаємовідносини держави та суспільства в Україні: управлінський аспект : монографія. Чернівці : Технодрук, 2010. $524 \mathrm{c}$.

5. Амосов О.Ю., Гавкало Н.Л. Публічне адміністрування: методологічний контекст. Публічне управління XXI століття: від соиіального діалогу до суспільного консенсусу: збірн. тез до XIV Міжнар. наук. конгресу. Харків: Магістр, 2014. С. 12-13. 
6. Бугайчук К. Процес публічного адміністрування в органах національної поліції України. Підприємництво, господарство і право. 2019. № 3. C. 137-142.

7. Гошовська В.А. Публічна політика; Енииклопедичний словник з державного управління; уклад.: Ю. Сурмін, В. Бакуменко, А. Михненко [та ін.]. Київ : НАДУ, 2010. С. 604-605.

8. Демократичні стандарти врядування ци публічного адміністрування: матер. наук.-практ. конф. за міжнар. участю (м. Львів, 4 квітня 2008 р.). У 2 ч. Ч. 1. Львів: ЛРІДУ НАДУ, 2008. 561 с.

9. Демченко Л. Критика теорії і практики бюрократії. Public Administartion Aspects. 2019. № 7(5). С. 5-11.

10. Джафарова О.В. Дослідження органів публічної адміністрації в системі суб'єктів дозвільної діяльності в Україні. Форум права. 2018. C. $42-49$.

11. Дзюндзюк В.Б., Мельтюхова Н.М., Фоміцька Н.В. Публічне адміністрування в Україні. Харків : Магістр, 2011. 306 с.

12. Енциклопедія державного управління: у 8 тт. Т. 8 : Публічне врядування / наук. ред. кол. : В.С. Загорський та ін. Львів : ЛРІДУ, НАДУ. 2011. $712 \mathrm{c}$.

13.Зарічний О.А. Участь громадськості у здійсненні публічної влади: теоретико-правове дослідження : дис. ... канд. юрид. наук. Львів, 2017. 229 c.

14. Золотарьова М.К. Адміністративно-правовий статус державних податкових інспекцій : монографія. Запоріжжя : КПУ, 2010. 164 с.

15. Кальниш Ю.Г., Лозинська Т.М., Тимцуник В.І. Публічне адміністрування : навч. посіб. Полтава : РВВ ПДАА, 2015. 185 с.

16. Кілієвич О. Англо-український глосарій термінів і понять 3 аналізу державної політики та економіки. Київ : Основи, 2003. 510 с.

17. Колесникова К.О. Публічне адміністрування в Україні: огляд літературних джерел. URL : http//www.kbupapa.kharkov.ua/ebook/tpdu/2013-3/doc/l/16.pdf (дата звернення: 24.10.2020).

18. Лазор Л.Я., Лазор Л.Д. Публічне управління та адміністрування: ретроспектива деяких теоретичних аспектів. Університетські наукові записки. 2015. № 56. С. 111-121.

19. Методологія публічного управління: навчальний посіб. / укладач І.В. Шпекторенко. Дніпро : ДРІДУ НАДУ, 2018. 120 с. Міхровська М. Державне управління та публічна адміністрація: шлях до демократії. Вісник Київського національного університету імені Тараса Шевченка (Юридичні науки). 2011. № 88. С. 90-93.

20. Митяй О.В., Світовий О.М. Дослідження понять «державне управління» $\mathrm{i}$ «публічне адміністрування». Держава та регіони. Серія : Державне управління. 2018. № 1(61). С. 124-128. 
21. Молошна О.Л. Особливості формування державно-службових відносин в умовах становлення системи публічного адміністрування в Україні. URL : http://www.dridu.dp.ua/vidavnictvo/2009/2009-02(2)/ Moloshna,\% 20Bashtannyk.pdf (дата звернення: 24.10.2020).

22. Основи публічного адміністрування : навч. посібн. / за заг. ред. Н.П. Матюхіної. Харків : Право, 2018. 172 с.

23. Петров С.В. Феноменологія адміністративно-господарського права України : монографія. Харків : Диса плюс, 2012. 392 с.

24. Петровський П., Радченко О. Гуманітарна парадигма як теоретико-методологічна модель демократичного врядування. Ефективне державне управління: збірн. наук. пр. 2011. № 26. С. 13-22. Публічна адміністрація в Україні: становлення та розвиток : монографія / за заг. ред. А.В. Толстоухова. Дніпро : Монолит, 2010. 400 c.

25. Селіванов А.О. Публічна влада i громадянин в умовах застосування судової адміністративної юрисдикції (проблеми теорії і практики). Право Украӥни. 2006. № 9. С. 28-33.

26. Система адміністративного менеджменту та апарат управління. Адміністративний процес. URL : https://goo.gl/EJat4y (дата звернення: 24.10.2020).

27. Стеценко С.Г. Адміністративне право України : навч. посіб. Київ : Атіка, 2011. 624 с.

28. Школик А.М. Порівняльне адміністративне право. Львів : ЗУКЦ, $2007.308 \mathrm{c}$.

29. Шумляєва І. Розвиток взаємовідносин органів публічної влади та громадян на місцевому рівні в умовах формування правової держави. Державне управління та місиеве самоврядування. 2019. Вип. 2(41). С. $157-165$.

30. Andersen S., Burns T. The European Union and the erosion of parliamentary democracy: a study of post-parliamentary governance. The European Union: how democratic is it? London : Sage, 1996.

31. Habermas, J. (1992), Further Reflections on the Public Sphere. Habermas and the public sphere / edited by C. Calhoun. The MIT Press, Cambridge, Massachusetts, and London, England, pp. 421-461. URL : http://courses.ischool.berkeley.edu/i218/s15/calhoun_BPSIntroduction.pdf.

\section{Information about the author: Blikhar M. M.,}

Doctor of Juridical Sciences, Associate Professor, Professor at the Department of Administrative and Informational Law Lviv Polytechnic National University 12, Bandera str., Lviv, 79013, Ukraine 